\title{
PENERAPAN MODEL PEMBELAJARAN PROBLEM SOLVING UNTUK MENINGKATKAN PRESTASI BELAJAR FISIKA SISWA KELAS XII IPA 6 SEMESTER 1 SMA NEGERI 2 DENPASAR TAHUN PELAJARAN 2017 / 2018
}

\author{
Regina Maria Mudji Sri Emilijani \\ SMA Negeri2 Denpasar \\ E.mail: reginamaria@gmail.com
}

\begin{abstract}
ABSTRAK
Penelitian tindakan kelas ini dilaksanakan pada siswa kelas XII- 6 semester 1 tahun ajaran 2017/ 2018 yang kemampuan siswanya untuk materi pembelajaran "Gelombang Bunyi dan Gelombang Cahaya " sangat rendah. Tujuan penulisan penelitian tindakan kelas ini adalah untuk mengetahui seberapa tinggi peningkatan prestasi belajar siswa dalam mata pelajaran fisika setelah diterapkan model pembelajaran problem Solving menggunakan teori-teori yang benar dalam pelaksanaan pembelajaran Fisika. Metode pengumpulan datanya adalah tes prestasi belajar Fisika. Metode analisis datanya adalah deskriptif baik untuk data kualitatif maupun untuk data kuantitatif. Hasil dari penelitian ini menunjukkan bahwa penerapan model pembelajaran Problem Solving dapat meningkatkan prestasi belajar siswa. Hal ini terbukti dari prestasi belajar yang diperoleh siswa pada awalnya mencapai nilai rata-rata 62,61, pada siklus I mencapai nilai rata-rata 81,56danpadasiklus II mencapainilai rata-rata 83,65. Dari hasil penelitian tersebut dapat disimpulkan bahwa penerapan model pembelajaran Problem Solving menggunakan teori-teori yang benar dapat meningkatkan prestasi belajar siswa pada mata pelajaran Fisika
\end{abstract}

Kata kunci: Model PembelajaranProblem Solving, Prestasi Belajar Siswa.

\begin{abstract}
This classroom action research was conducted on students of class XII-6 in the first semester in academic year 2017/2018 with low ability in learning "Sound Waves and Light Waves". The purpose of this study is to find out how high the improvement in student learning achievement in physics subjects after the problem solving learning model is applied using the correct theories in the implementation of learning physics. The data collection method is a physics learning achievement test. The data analysis method is descriptive both for qualitative data and for quantitative data. The results of this study indicated that the application of the problem solving learning model can improve student learning achievement. This is evident from the learning achievements obtained by students at first reached an average value of 62.61, in the first cycle reached an average value of 81.56 and in the second cycle achieved an average value of 83.65. From the results of these studies it can be concluded that the application of the problem solving learning model using the correct could improve student learning achievement in Physics subjects
\end{abstract}

Key words:Learning Model Problem Solving, Student Learning Achievement. 


\section{PENDAHULUAN}

Salah satu dampak dari reformasi total yang terjadi di Indonesia adalah melahirkan isu tentang perbaikan kualitas pendidikan. Perubahan yang tampak dari reformasi tersebut adalah perubahan paradigm pendidikandari sudut pengelolaan pendidikan yang dulunya bersifat sentralistik menjadi desentralistik, dari pendekatan parsial-sektoral ke holistik-intersektoral, dari penyelenggaraan kegiatan belajar teacher centered ke student centered, dari mutu pendidikan yang berwawasan lokal nasional ke mutu pendidikan bertaraf internasional (Wina Sanjaya. 2006).

Undang-undang Nomor 20 Tahun 2003 tentang sistem pendidikan nasional, telah membuka paradigma baru dalam praktik pendidikan yang pada hakikatnya lebih menekankan pada proses pelaksanaan pembelajaran dari pada output sebagai hasil pembelajaran. Pada pasal 1 ayat (1) undang-undang nomor 20 tahun 2003, menyatakan bahwa pendidikan sebagai usaha sadar untuk mewujudkan suasana belajar dan proses pembelajaran agar peserta didik secara aktif mengembangkan potensi dirinya untuk memiliki kekuatan spiritual keagamaan, pengendalian diri, kepribadian, kecerdasan, akhlak mulia, serta ketrampilan yang diperlukan dirinya, masyarakat, bangsa dan negara. Hal ini mengandung makna bahwa paradigma baru pendidikan harus lebih menekankan kepada proses pembelajaran.

Pelaksanaan pembelajaran di kelas akan lebih efektif apabila guru sebagai pengajar mampu memahami peran, fungsi dan kegunaan mata pelajaran yang diajarnya. Untuk mengetahui dan memahami secara efektif mengenai peran, fungsi dan kegunaan mata pelajaran yang diajarkan guru dapat diketahui melalui proses pembelajaran di kelas. Selain pemahaman terhadap hal-hal seperti uraian tersebut di atas, efektivitaspembelajaran juga ditentukan oleh kemampuan guru untuk merubah model pengajaran menjadi model pembelajaran sesuai yang diharapkan oleh Permen No. 41 tahun 2007 tentang Standar Proses.

Problem solving merupakan salah satu model pembelajaran aktif yang relevan dengan materi pembelajaran fisika yang membutuhkan keterampilan kognitif siswa untuk melakukan eksplorasi, berpikir kritis, serta aktif dan mampu memecahkan persoalan yang dihadapi dalam belajar. Menurut Bonwell seperti dikutip Semadhi (2005), pembelajaran aktif memiliki karakteristik sebagai berikut: (1) lebih menekankan pada pendekatan proses pembelajaran, bukan berorientasi pada penyampaian informasi oleh pengajar melainkan berorientasi pada pengembangan keterampilan, serta pemikiran analitis dan kritis terhadap topik atau permasalahan yang akan dibahas, (2) siswa tidak hanya mendengarkan pelajaran secara pasif tetapi mengerjakan sesuatu yang berkaitan dengan materi pelajaran, (3) lebih menekankan pada eksplorasi nilai-nilai dan sikap berkenaan dengan materi pelajaran, (4) siswa lebih banyak dituntut untuk berpikir kritis, menganalisis serta melakukan evaluasi, dan (5) umpan balik yang lebih cepat akan terjadi pada proses pembelajaran.

Dari semua uraian di atas dapat diketahui hal-hal yang perlu dalam upaya meningkatkan aktivitas dan prestasi belajar siswa seperti penguasaan metode-metode ajar, penguasaan model-model pembelajaran, penguasaan teori-teori belajar, penguasaan teknik-teknik tertentu, penguasaan peran, fungsi serta kegunaan 
mata pelajaran. Apabila betul-betul guru menguasai dan mengerti tentang hal-hal tersebut dapat diyakini bahwa prestasi belajar siswa pada mata pelajaran fisika tidak akan rendah. Namun kenyataannya prestasi belajar siswa kelasXII IPA 6 di semester I tahun ajaran semester I baru mencapai nilai rata-rata 62,61 yang masih jauh dari kriteria ketuntasan minimal (KKM) yaitu 78 .

Rendahnya prestasi belajar siswa kelasXII IPA 6 SMA Negeri 2 Denpasar yang tercermin dari nilai tes hasil ulangan harian pada semester Itahun pelajaran 2017/ 2018 tersebut, disebabkan oleh beberapa faktor, antara lain: (1) rendahnya kualitasproses pembelajaran, dimana siswa mengalami kesulitan dalam menemukan pola yang baik untuk mengembangkan pemahaman dalam belajar fisika, (2) guru mengalami kesulitan dalam mengembangkan rancangan pembelajaran yang sesuai, sehingga terkesan monoton, (3) siswa masih ragu dan takut dalam mengemukakan ide-ide dalam mengembangkan pola berpikir yang mengakibatkan rendahnya motivasi untuk meningkatkan kemampuan mereka dalam belajar, dan (4) penerapan metode pembelajaran kurang tepat bila dilihat dari karakteristik pembelajaran fisika saat ini.

Model pembelajaran yang relevan dengan permasalahan yang dihadapi guru seperti uraian tersebut di atas adalah model pembelajaran problem solving. Hal ini didasarkan atas pemikiran bahwa problem solvingmerupakan salah satu model pembelajaran yang dirancang berdasarkan kemampuan siswa dalam pemecahan masalah terkait materi pembelajaran yang diajarkan untuk memperoleh jawaban atau solusi yang terbaik sehingga dapat meningkatkan motivasi siswa dalam belajar yang akan bermuara pada peningkatan prestasi belajar siswa.

Bercermin dari kesenjangan antara harapan dengan kenyataan yang terjadi seperti uraian tersebut di atas, maka dipandang perlu untuk melakukan inovasi terhadap pendekatan pembelajaran yang diterapkan di kelas. Salah satunya adalah perbaikan pembelajaran dengan menggunakan model pembelajaran problem solving. Bertitik tolak dari hal ini mendasari peneliti untuk meneliti tentang "PenerapanModel Pembelajaran Problem Solving sebagai UpayaMeningkatkan Prestasi Belajar FisikaSiswa Kelas XII IPA 6Semester I SMA Negeri 2 Denpasar Tahun Ajaran 2017/2018".

Melihat adanya kesenjangan antara harapan dengan kenyataan yang ada di lapangan seperti yang sudah dipaparkan pada latar belakang masalah, maka permasalahan yang dapat dirumuskan dalam penelitian ini adalah sebagai berikut: Apakah penerapan model pembelajaran problem solving dapatmeningkatkan prestasi belajar fisika siswa kelas XII IPA 6semester I SMA Negeri 2 Denpasar tahun ajaran 2017/ 2018?

Berdasarkan rumusan masalah yang telah disampaikan seperti tersebut di atas, tujuan yang ingin dicapai dari penelitian ini adalah untuk mengetahui seberapa tinggi peningkatan prestasi belajar fisikasiswa kelas XII IPA 6 Semester I SMA Negeri 2 Denpasar tahun ajaran 2017/2018setelah penerapan model pembelajaran problem solving dalam pelaksanaan pembelajaran fisika dengan hasil yang masimal.

Kemampuan siswa untuk memecahkan masalah (problem solving) dalam pelaksanaan pembelajaran sangat diperlukan. Pelaksanaan pembelajaran melalui pemecahan masalah di sekolah dapat membantu siswa dalam mempelajari 
konsep-konsep dan prinsip-prinsip utama, serta menerapkannya dalam pemecahan masalah yang mereka hadapi dalam pelaksanaan pembelajaran (Depdiknas, 2002). Pemecahan masalah (problem solving) merupakan model pembelajaran yang didasarkan atas melatih kemampuan siswa dalam memecahkan suatu persoalan atau permasalahan. Persoalan atau permasalahan tersebut mungkinberasal dari guru, dari suatu fenomena tertentu, atau persoalan yang dijumpai dalam kehidupan sehari-hari oleh siswa. Persoalan tersebut diajukan setelah siswa diberikan pengetahuan terkait permasalahan dan tehnik pemecahan masalah yang mesti dilakukan. Dalam pemecahan masalah (problem solving), siswa berpikir dan bernalar untuk mengaplikasikan pengetahuan-pengetahuan yang telah diperoleh sebelumnya untuk memecahkan masalah-masalah baru yang belum pernah dijumpai sebelumnya.

Cholis (2002, dalam Wardani, 2011) menyebutkan bahwa ada beberapa hal yang perlu diperhatikan dalam pembelajaran pemecahan masalah (problem solving), yaitu: (1) menentukan permasalahan yang akan disajikan disesuikan dengan materi, (2) masalah yang disajikan harus mampu mendorong siswa berpikir dari berbagai sudut pandang yang berbeda, (3) masalah harus disesuaikan dengan dengan tingkat kemampuan siswa, (4) masalah harus jelas, dan (5) masalah dikaitkan dengan dunia nyata dan cukup menarik siswa.

Melihat karakteristik dan langkah-langkah model pembelajaran problem solving dalam memecahkan masalah yang ada dalam pembelajaran fisika yang telah disampaikan, maka hipotesis tindakan ini dapat dirumuskan seperti berikut: Penerapan model pembelajaran problem solving dapatmeningkatkan prestasi belajar fisika siswa kelas XII IPA 6semester I SMA Negeri 2 Denpasar tahun pelajaran2017/ 2018.

\section{METODE PENELITIAN}

Penelitian tindakan kelas ini dilakukan pada siswa kelas XII IPA 6semester I SMA Negeri 2 Denpasar tahun pelajaran 2017/ 2018. Sekolah ini berlokasi di Jalan Sudirman Denpasar. Sekolah ini didukung oleh suasana pembelajaran yang rindang, nyaman, dan sejuk mengingat beberapa pohon penyejuk tertanam di halaman sekolah. Di samping itu, sekolahdikelilingi dengan pagar berduri sehingga aman dari gangguan yang dapat mengancam proses pembelajaran. Dipilihnya SMA Negeri 2 Denpasar sebagai tempat penelitian mengingat peneliti sendiri bertugas sebagai guru bidang studi fisika di sekolah ini, sehingga memudahkan peneliti dalam memperoleh data dan melakukan observasi terhadap subjek dan objek penelitian.

Penelitian yang dilakukan ini termasuk penelitian tindakan kelas (class action research). Penelitian tindakan dirancang secara khusus dalam melakukan sebuah penelitian yang didasari atas filosofi bahwa setiap manusia selalu ingin mendapatkan sesuatu yang lebih baik dari sebelumnya. Peningkatan diri untuk hal yang lebih baik ini dilakukan secara berkesinambungan sampai tujuan yang telah dirumuskan sebelumnya dapat tercapai (Suharsimi Arikunto, Suhardjono, Supardi, 2006).

Dalam penelitian ini penulis memilih rancangan penelitian tindakan kelas yang umum dugunakan, yaitu rancangan yang disampaikan oleh Hopkins (1993, dalam Suharsimi Arikunto, 
Suhardjono, Supardi, 2006) seperti terlihat pada gambar berikut.

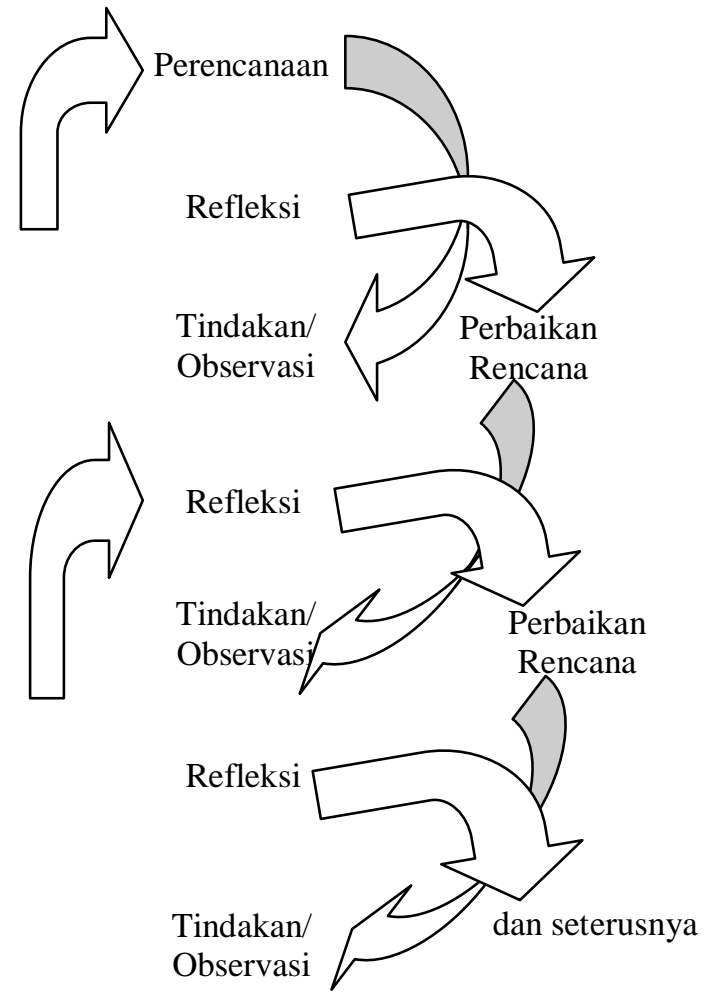

Gambar: Alur Penelitian Tindakan Kelas

Penelitian ini mengambil subjek penelitian semua siswa kelas XII IPA 6semester ISMA Negeri 2 Denpasar tahun pelajaran 2017-2018yang berjumlah 43 orang siswa, yang terdiri dari 17 orang laki-laki dan 26orang perempuan. Karakteristik dari subjek penelitian ini dapat diuraikan sebagai berikut.Semua siswa tidak termasuk siswa kelas unggulan dengan kemampuan rata-rata sedang sampai kurang dengan memperhatikan proses belajar mereka. Penilaian awal yang telah dilaksanakan mencerminkan hasil sebagai berikut: rata-rata 62,61 , daya serap $62,61 \%$, nilai tertinggi 99 , nilai terendah 32, dan ketuntasan secara klasikal sebesar $23,26 \%$.

Sedangkan objek dalam penelitian ini adalah peningkatan prestasi belajar siswa kelas XII IPA 6 SMA Negeri 2 Denpasar pada semester Itahun pelajaran 2017-2018setelah diterapkan model pembelajaran problem solving dalam proses pembelajaran fisika.

Penelitian ini dilakukan dari bulan Juli sampai dengan bulan September 2017.sumber data dalam penelitian tindakan kelas ini adalah semua siswakelas XII IPA 6 SMA Negeri 2 Denpasar pada semester I tahun pelajaran 2017/ 2018.

Adapun indikator yang digunakan untuk menentukan keberhasilan pelaksanaan tindakan sebagai berikut. KKM (Kriteria Ketuntasan Minimal) untuk kelas XII IPA 6 SMA Negeri 2 Denpasar pada semester I adalah 78 untuk tahun tahun pelajaran 2017/2018. Apabila secara klasikal siswa sudah $90 \%$ yang memperoleh nilai tes akhir $\geq 75$ (nilai KKM) penelitian tindakan dikatakan sudah berhasil.

\section{HASIL PENELITIAN DAN PEMBAHASAN}

Pada bagian ini, akan dipaparkan data yang diperoleh dari penelitian tindakan secara rinci berdasarkan penelitian yang dilakukan pada siswakelas XII IPA 6 SMA Negeri 2 Denpasar di semester I tahun pelajaran 2017/2018.

\section{Deskripsi Kondisi Awal}

Sebagaimana telah diuraikan pada bab pendahuluan tepatnya pada subbab latar belakang yang berhubungan dengan subjek penelitian, bahwa kemampuan siswa kelas XII IPA 6 SMA Negeri 2 Denpasar pada semester I dalam memahami dan menyelesaikan soal-soal yang berkaitan dengan fisika masih sangat kurang dalam kompetensi dasar melakukan kajian ilmiah untuk mengenali gejala dan ciri-ciri gelombang bunyi serta penerapannya dalam teknologi.

Data akurat tentang kondisi awal 
siswa sudah diuraikan pada perolehan hasil belajar dimana rata-ratanya adalah 62,61 , median 62, modus 89, ketuntasan belajar $62,61 \%$, siswa yang perlu diremidi 33 orang, dan siswa yang perlu diberi pengayaan sebanyak 10 orang.

\section{Deskripsi Siklus I}

Tindakan siklus I dilaksanakan hari Senin, tanggal 13 dan 20Agustus 2017, siswa yang hadir 43 orang. Pada siklus ini diterapkan rencana tindakan yang terdapat pada skenario pembelajaran RPP. Pelaksanaan siklus I secara rinci diuraikan pada bagian berikut ini.

Hasil tes akhir siklus I menunjukkan bahwa kemampuan siswa untuk menyelesaikan soal-soal yang berkaitan dengan mata pelajaran fisika pada kompetensi dasar melakukan kajian ilmiah untuk mengenali gejala dan ciri-ciri gelombang bunyi serta penerapannya dalam teknologiberada pada kategori cukup baik, karena rata-rata $(\overline{\mathrm{X}})$ secara klasikal 81,56 berada pada interval $80 \leq \overline{\mathrm{X}}<89$ (kategori baik). Secara rinci dapat diuraikan bahwa dari 43 orang siswa, 4 orang dapat nilai terendah: 77 yaitu subjek penelitian dengan nomor absen 11, 19, 26, dan 41, nilai tertinggi: 85 , yaitu subjek penelitian dengan nomor absen $7,8,13$, dan 38. Jumlah nilai seluruh siswa adalah 3.507. Dengan demikian rata-rata kelas dapat dihitung dengan rumus:

$$
\begin{gathered}
\bar{X}=\frac{\sum_{i=1}^{n} X i}{n}=\frac{3.507}{43} \\
=81,56 . \\
\text { Keterangan: } \\
\bar{X} \quad=\text { rata-rata kelas } \\
\sum_{i=1}^{n} X i
\end{gathered}
$$

$$
=\text { jumlah nilai seluruh }
$$$$
\text { siswa }
$$

$\mathrm{n} \quad=$ banyak siswa yang memiliki nilai itu (siswa yang ikut tes)

Selanjutnya dapat dihitung daya serap (DS) siswa dengan rumus:

$$
\begin{aligned}
\text { DS } & =\frac{\bar{x}}{100} \times 100 \% \\
& =\frac{81,56}{100} \times 100 \% \\
& =81,56 \% .
\end{aligned}
$$

Keterangan:

\begin{tabular}{|c|c|c|c|c|c|}
\hline No & $\begin{array}{l}\text { Nilai } \\
\text { Tes } \\
(\mathrm{N})\end{array}$ & $\begin{array}{c}\text { Frekue } \\
\text { nsi } \\
(\mathrm{F})\end{array}$ & $\mathrm{N} \times \mathrm{F}$ & $\begin{array}{l}\text { No. } \\
\text { Absen } \\
\text { Siswa }\end{array}$ & Ket \\
\hline 1. & 77 & 4 & 308 & $\begin{array}{l}11, \\
19\end{array}$ & $\begin{array}{l}\text { Belum } \\
\text { tuntas }\end{array}$ \\
\hline
\end{tabular}

$\mathrm{DS}=$ daya serap

$\overline{\mathrm{X}} \quad=$ rata-rata kelas

Dari jumlah 43 orang siswa, 39 orang sudah tuntas, sedangkan 4orang masih belum tuntas, ketuntasan secara klasikal dapat dihitung dengan rumus:

$$
\begin{aligned}
& \text { KetuntasanBelajar }= \\
& \begin{array}{c}
\text { Jumlah siswa yang mendapat nilai } \geq 78 \text { (nilai KKM) } \\
\text { Banyaknya }
\end{array} \text { siswa yang ikut tes } \\
& =\quad \frac{39}{43} \times 100 \%=90,70 \% .
\end{aligned}
$$

Tabel Rekapitulasi Perolehan Nilai Prestasi Belajar Siswa Siklus I

\begin{tabular}{|c|c|c|c|}
\hline & & & 43. \\
\hline 4. 82 & 14 & 1.148 & $\begin{array}{lll}1, & 5, & \text { Tuntas } \\
6, & 9, & \\
14 & & \end{array}$ \\
\hline
\end{tabular}

\begin{tabular}{llcclll} 
& & & \multicolumn{3}{c}{$\begin{array}{l}26, \& \\
41 .\end{array}$} \\
\hline 2. & 78 & 1 & 78 & 17. & Tuntas \\
\hline 3. & 81 & 14 & 1.134 & 2, & 4, & Tuntas
\end{tabular}
12 , 15 , 16 , 18 , 28 , 31 , 32 , 33 , 35 , 37,40 dan 


\begin{tabular}{|c|c|c|c|}
\hline & & & $\begin{array}{l}20, \\
23, \\
24, \\
25, \\
27, \\
29, \\
30, \\
34, \quad \& \\
36 .\end{array}$ \\
\hline 5. 83 & 5 & 415 & $\begin{array}{l}3,10, \text { Tuntas } \\
21, \\
22, \& \\
42\end{array}$ \\
\hline 6. 84 & 1 & 84 & 39. Tuntas \\
\hline 7. 85 & 4 & 340 & $\begin{array}{lll}7, & 8, & \text { Tuntas } \\
13, & \& & \\
38 . & & \\
\end{array}$ \\
\hline Jumlah & 43 & 3.507 & \\
\hline Rata-rata & & 81,56 & \\
\hline DS & & $81,56 \%$ & \\
\hline PKB & & $90,70 \%$ & \\
\hline
\end{tabular}

Berdasarkan data di atas jika dibandingkan dengan hasil tes akhir dapat disampaikan bahwa pada siklus I yang tuntas adalah 39 orang siswa $(90,70 \%)$.

Tabel. Hasil Analisis Data Tes Akhir Siklus I Selisih Nilai

\begin{tabular}{|c|c|c|c|}
\hline Uraian & Awal & Siklus I & $\begin{array}{c}\text { Awal dan } \\
\text { Siklus I } \\
\left(\mathrm{X}_{2}-\mathrm{X}_{1}\right)\end{array}$ \\
\hline $\begin{array}{l}\text { Jumlah } \\
\text { Nilai } \\
\text { klasikal }\end{array}$ & 2.973 & 3.507 & \\
\hline Rata-rata & 62,61 & 81,56 & \\
\hline $\begin{array}{l}\text { Daya } \\
\text { Serap (DS) }\end{array}$ & $62,61 \%$ & $81,56 \%$ & \\
\hline $\begin{array}{l}\text { Ketuntasan } \\
\text { Belajar }\end{array}$ & $23,26 \%$ & $90,70 \%$ & \\
\hline Kategori & $\begin{array}{l}\text { Sangat } \\
\text { Kurang }\end{array}$ & Baik & \\
\hline
\end{tabular}

Untuk penyajian dalam bentuk grafik, maka hal-hal berikut dihitung terlebih dahulu.

a. $\operatorname{BanyakKelas}(\mathrm{K})=1+3,3 \times \log (\mathrm{N})$

$$
\begin{array}{ll}
= & 1+3,3 \log 43 \\
= & 1+(3,3 \times 1,63) \\
= & 1+5,38=6,38 \rightarrow 6
\end{array}
$$

b. $\quad$ RentangKelas $(\mathrm{r})=$ skormaksimum - skor minimum

$$
=85-77
$$

$=8$

\begin{tabular}{|c|c|c|c|c|}
\hline $\begin{array}{l}\text { No } \\
\text { Urut }\end{array}$ & Interval & $\begin{array}{l}\text { Nilai } \\
\text { Tengah }\end{array}$ & $\begin{array}{c}\text { Frek. } \\
\text { Absolut }\end{array}$ & $\begin{array}{l}\text { Frek. } \\
\text { Relatif }\end{array}$ \\
\hline 1 & $77-78$ & 77,5 & 5 & 11,63 \\
\hline 2 & $79-80$ & 79,5 & 0 & 0 \\
\hline 3 & $81-82$ & 81,5 & 28 & 65,12 \\
\hline 4 & $83-84$ & 83,5 & 6 & 13,95 \\
\hline 5 & $85-86$ & 85,5 & 4 & 9.30 \\
\hline 6 & $87-88$ & 87,5 & 0 & 0 \\
\hline \multicolumn{3}{|c|}{ Total } & 43 & 100 \\
\hline
\end{tabular}

c. PanjangKelas Interval (i) = $\frac{r}{K}=\frac{8}{6}=1,3 \rightarrow 1$

Tabel Interval KelasSiklus I

Histogram prestasi belajar fisika siswa kelas XII IPA 6Semester I SMANegeri 2 Denpasar tahun ajaran 2017/ 2018pada siklus I sesuai dengan gambar 02, yaitu sebagai berikut.

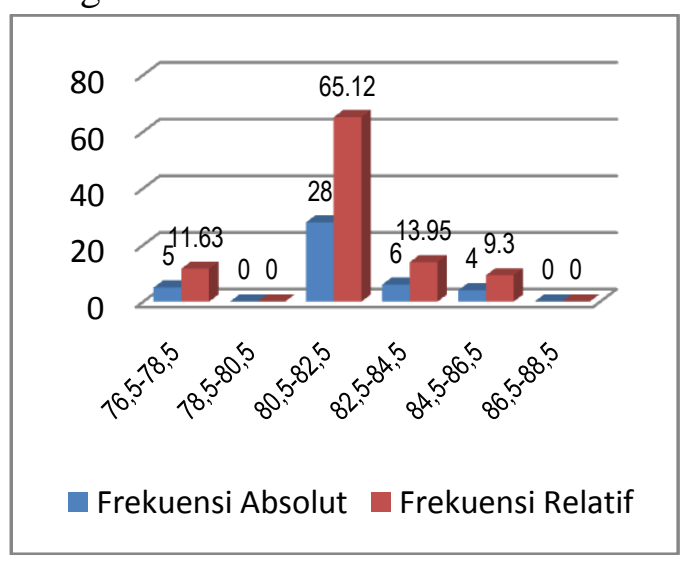

\section{Deskripsi Siklus II}

Tindakan siklus II dilaksanakan hari Senin, tanggal 18 dan 25 September 2017, siswa yanghadir 43orang. Pada siklus ini diterapkan rencana tindakan yang terdapat pada skenario pembelajaran siklus II.

Pada siklus II, proses pembelajaran yang dilakukan guru sudah sesuai dengan rencana.Dengan memberikan arahan, penjelasan, motivasi mengenai pentingnya mempelajari fisika yang dapat digunakan dalam pemecahan masalah berkaitan dengan kehidupan sehari-hari. Dengan demikian, diupayakan keaktifan siswa 
makin meningkat baik, kemauan kerja siswa semakin meningkat dan lebih antusias untuk menerima pelajaran yang diberikan.

Sedangkan kelebihan-kelebihan yang diperoleh pada siklus II adalah terbentuknya pengaruh positif dari sikus II jika dibandingkan dengan pembelajaran siklus I. Metode belajar siswa sudah mengalami perubahan yang pesat terutama respon siswa sudah sangat antusias, banyak siswa yang lebih kereatif, mau berpartisipasi secara aktif menyampaikan pendapat dan memberikan bantuan kepada siswa yang belum memahami materi dalam kegiatan pembelajaran yang diberikan.

\section{Hasil Observasi/ Pengamatan Siklus II}

Pengumpulan data dari hasil pengamatan/ observasi dilakukan dengan memberikan tes prestasi belajar fisika. Pada saat membagikan atau pada saat memberikan tes, guru giat memotivasi siswa agar mereka bekerja sendiri dan tidak bekerjasama. Situasi itu dituntut agar hasil dari pelaksanaan penelitian ini dapat lebih sempurna. Hasil observasi yang dilakukan disampaikan pada tabel berikut.

Tabel. Prestasi Belajar Fisika Siswa pada Siklus II

\begin{tabular}{|c|c|}
\hline Jumlah Nilai kelas & 3.597 \\
\hline Rata-rata & 83,65 \\
\hline $\begin{array}{l}\text { KKM (Kriteria } \\
\text { Ketuntsan Minimal) }\end{array}$ & 78 \\
\hline $\begin{array}{l}\text { Jumlah yang sudah } \\
\text { tuntas }\end{array}$ & 43 \\
\hline $\begin{array}{l}\text { Jumlah siswa yang } \\
\text { belum tuntas }\end{array}$ & 0 \\
\hline $\begin{array}{ll}\text { Persentase ketuntasan } \\
\text { belajar }\end{array}$ & $100 \%$ \\
\hline
\end{tabular}

Tes akhir siklus II dilaksanakan pada hari Rabu, tanggal 06 September2017, yang hadir 43 orang. Dari penerapan tindakan siklus II tersebut diperoleh nilai di bawah ini.

Hasil tes akhir siklus II menunjukkan bahwa kemampuan siswa mengaplikasikan model pembelajaran pada menyelesaikan soal-soal kompetensi dasar melakukan kajian ilmiah untuk mengenali gejala dan ciri-ciri gelombang bunyi serta penerapannya dalam teknologi, berada pada ketegori sangatbaik karena rata-rata $(\bar{X})$ secara klasikal 83,65 berada pada interval $90 \leq \bar{X}<100$. Secara rinci dapat diuraikan bahwa dari 43 orang siswa, 1 orang dapat nilai terendah: 80 yaitu subjek penelitian dengan nomor absen 26, sedangkan 2 orang siswa mendapat nilai tertinggi: 88 yaitu subjek penelitian dengan nomor absen 7, 8, dan 38. Jumlah nilai seluruh siswa adalah 3.597, dengan demikian rata-rata kelas dapat dihitung dengan rumus:

$$
\begin{aligned}
\bar{X} & =\frac{\sum_{i=1}^{n} X i}{3.597} \\
& =\frac{43}{} \\
& =83,65 .
\end{aligned}
$$

Keterangan:

$$
\begin{aligned}
\frac{\sum_{i=1}^{\bar{X}} X i}{n} & \begin{array}{l}
\text { jumlah nilai seluruh } \\
\text { siswa }
\end{array} \\
\mathrm{n} & =\begin{array}{l}
\text { banyak siswa yang } \\
\text { memiliki nilai itu } \\
\text { (siswa yang ikut tes) }
\end{array}
\end{aligned}
$$

Selanjutnya dapat dihitup daya serap (DS) siswa dengan rumus:

DS

$$
\begin{aligned}
& =\frac{\bar{x}}{100} \times 100 \% \\
& =\frac{83,65}{100} \times 100 \%= \\
& 83,65 \% .
\end{aligned}
$$

Keterangan:

$$
\begin{array}{ll}
\mathrm{DS} & =\text { daya serap } \\
\overline{\mathrm{X}} & =\text { rata-rata kelas }
\end{array}
$$

Dari jumlah 43 orang siswa, semuasiswa sudah berhasil tuntas dalam 
mengikuti pembelajaran fisika.Ketuntasan secara klasikal dapat dihitung dengan rumus:

Ketuntasan Belajar $=$

$\frac{\text { Jumlah siswa yang mendapat nilai } \geq 78 \text { (nilai KKM) }}{\text { Banyaknya siswa yang ikut tes }} \times 100 \%$ $=\frac{43}{43} \times 100 \%=$
$100 \%$

Ketuntasan belajar secara klasikal pada siklus II sudah ada peningkatan yang sangat signifikan dan sudah berada pada kategori amat baik. Lebih jauh dapat diuraikan sebagai berikut:

Perbandingan antara hasil tes akhir siklus I dengan siklus II adalah:

(1) hasil tes siklus I yang tuntas 39 orang siswa $(90,70 \%)$ sedangkan pada siklus II semua siswa mencapai tuntas, (2) soal pilihan ganda soal nomor 13 untuk menentukan jawaban yang tepat masih mengalami masalah, karena untuk memodifikasi model pembelajaran yang diterapkan belum dipahami siswa, dan (3) soal nomor 36 soal uraian menjawabnya belum sesuai dengan harapan terutama untuk menentukan ciri-ciri gelombang bunyi serta penerapannya dalam teknologi.Untuk itu masih mengalami kesulitan dan masih perlu diberikan pemahaman secara gamlang dan mendetail sehingga siswa lebih termotivasi untuk mempelajari materi-materi berikutnya.

Berpedoman pada analisis data seperti yang diuraikan di atas, selanjutnya diadakan pertemuan dengan teman-teman guru sejawat untuk membahas kendala-kendala yang ditemukan pada siklus II. Karena respon siswa rata-rata skornya amat baik dan tampak sangat positif atau berapa pada kategori sangat positif setelah dikonfirmasikan dengan pedoman yang telah ditetapkan yaitu berada pada interval $\overline{\mathrm{T}} \geq 90$ (kategori sangat positif). Dari hasil tersebut ada gambaran umum yang merupakan kelemahan yaitu masih ada siswa memilih item sangat tidak setuju dan tidak setuju yaitu: responden 01 pada item 8 dipilih sangat tidak setuju dan item 12 dipilih tidak setuju, dan responden 20 pada item 16 dipilih tidak setuju. Sedangkan responden yang lain sudah memilih item setuju malah sangat setuju walaupun masih memilih item ragu-ragu. Untuk prestasi belajar pada siklus II rata-rata secara klasikal ada pada kategori baik mencapai 83,65 berada pada interval $80 \leq \overline{\mathrm{X}}<90$ (kategori baik). Dengan demikian walaupun masih berada dalam kategori cukup baik, tetapi sudah mencapai target keberhasilan yaitu pada interval $80 \leq \overline{\mathrm{X}}<90$, yang berada pada kategori baik. Daya serap 83,65\% dengan KKM 78 maka ketuntasan belajar sudah mencapai $100 \%$. Walaupun respon siswa dan prestasi belajar siswa sudah meningkat, tetapi masih diperlukan upaya-upaya perbaikan yang lebih baik dan lebih gigih demi peningkatan mutu pendidikan.

Hasil pengamatan peneliti selama tindakan siklus II adalah untuk 2 kelompok yaitu kelompok IV dan VI, yang bermasalah pada siklus I sudah ada perubahan dua kelompok, tinggal satu kelompok yaitu kelompok VI,kerjasama pemecahan masalah dalam diskusi masih ada yang diam dan masih menunggu hasil temannya. Berdasarkan hal tersebut, maka untuk satu kelompok ini perlu bimbingan dan perhatian khusus agar semua kelompok bekerja dengan baik dan efektif.

Dengan perolehan hasil yang sudah dipaparkan maka proses penelitian sudah dapat diakhiri karena hasil yang didapat sesuai dengan kriteria keberhasilan penelitian. Untuk penyajian dalam bentuk grafik, maka hal-hal berikut dihitung terlebih dahulu.
a. $\quad$ BanyakKelas $(\mathrm{K})=1+3,3 \times \log (\mathrm{N})$

$$
\begin{aligned}
& =1+3,3 \log 43 \\
& =1+(3,3 \times 1,63)
\end{aligned}
$$$$
=1+5,38=6,38
$$ 


$$
\rightarrow 6
$$

b. RentangKelas ( $\mathrm{r})=$ skormaksimum - skor minimum $=88-80$

$=8$

c. PanjangKelas Interval (i) $=\frac{r}{K}=\frac{4}{8}=$ $0,5 \rightarrow 1$.

Tabel. Interval KelasSiklus II

\begin{tabular}{ccccc}
\hline $\begin{array}{c}\text { No } \\
\text { Urut }\end{array}$ & Interval & $\begin{array}{c}\text { Nilai } \\
\text { Tengah }\end{array}$ & $\begin{array}{c}\text { Frekuensi } \\
\text { Absolut }\end{array}$ & $\begin{array}{c}\text { Frekuensi } \\
\text { Relatif }\end{array}$ \\
\hline 1 & $80-81$ & 80,5 & 6 & 13,95 \\
\hline 2 & $82-83$ & 82,5 & 15 & 34,88 \\
\hline 3 & $84-85$ & 84,5 & 18 & 41,86 \\
\hline 4 & $86-87$ & 86,5 & 1 & 2,33 \\
\hline 5 & $88-89$ & 88,6 & 3 & 6,98 \\
\hline 6 & $90-91$ & 90,5 & 0 & 0 \\
& Total & & 43 & 100 \\
\hline
\end{tabular}

Histogram prestasi belajar fisikasiswa kelas XII IPA 6Semester I SMA Negeri 2 Denpasar tahun ajaran 2017/ 2018pada siklus II sesuai dengan gambar 03, yaitu sebagai berikut.

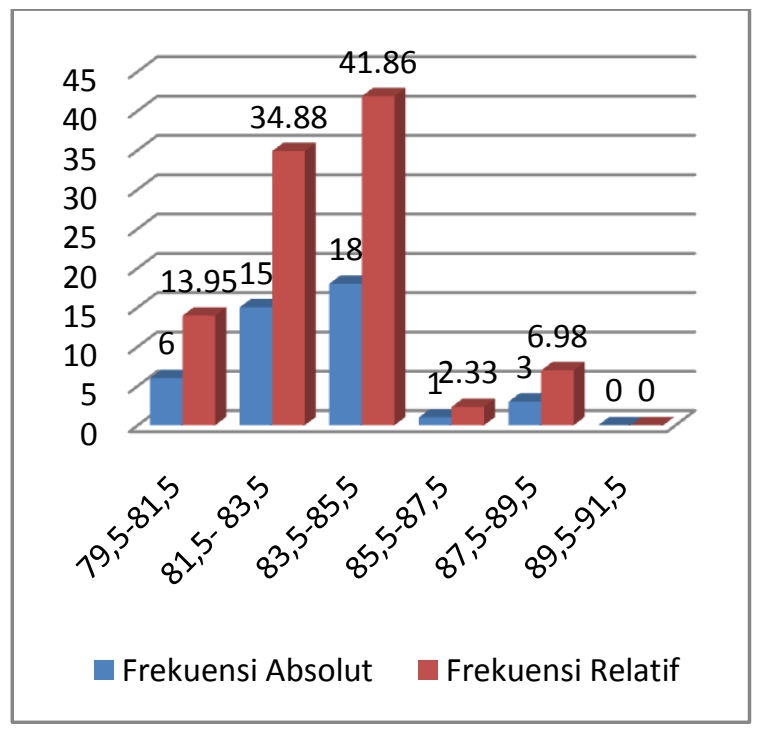

\section{Pembahasan}

Hasil penelitian tentang prestasi belajar fisika siswa menunjukkan rata-rata hasil yang dicapai pada siklus II lebih besar dibandingkan hasil yang dicapai pada siklus I dan lebih baik dari hasil awal. Untuk lebih jelasnya dapat diuraikan sebagai berikut.

1. Prestasi belajar fisika siswa pada awalnya rata-rata klasikal $(\overline{\mathrm{X}})$ adalah 62,61berada pada kategori urang, sedangkan pada siklus I rata-rata klasikal $(\overline{\mathrm{X}})$ adalah 81,56, berada pada kategori baik dan pada siklus II rata-rata klasikal $(\bar{X})$ adalah 83,65, berada pada kategori baik setelah dikonfirmasikan dengan pedoman yang ditetapkan.Dengan demikian data awal apabila dibandingkan dengan siklus I meningkat $\bar{X}_{1}-X_{2}=81,56-62,61=$ 18,95, sedangkan untuk siklus I ke siklus II meningkat $\overline{\mathrm{X}}_{2}-\overline{\mathrm{X}}_{3}=83,65-$ $81,56=2,09$. Demikian juga daya serap pada awalnya sebesar $62,61 \%$, pada siklus I sebesar $81,56 \%$ dan pada siklus II meningkat menjadi $83,65 \%$.

2. Ketuntasan belajar (KB) pada awalnya adalah 23,26\%, pada siklus I sebesar $90,70 \%$ dan pada siklus II meningkat menjadi $100 \%$.

Dalam penerapan model pembelajaran problem solving terlihat bahwa siswa dalam belajar Nampak menjadi lebih aktif, lebih kreatif, lebih menggairahkan dan lebih menyenangkan. Hal ini dapat dijelaskan sebagaiberikut: pada awal pembelajaran setiap siswa dikelompokkan secara heterogen danditentukan satu orang yang dianggap paling mampu untuk membimbing temannya yang kurang mampu. Setelah guru membuka pelajaran, dilanjutkan dengan membagikan LKS yang sama pada setiap kelompok yang diupayakan agar setiap siswa memiliki kewajiban dan tanggung jawab secara perorangan untuk mendiskusikan pada kelompoknya dalam menyelesaikan masalah yang tertulis di LKS yang diberikan kemudian sebagai bahan anggota kelompok untuk berdiskusi 
dalam kelompok.Siswasendiri mengkonstruksi dengan pengalaman yang dimiliki untuk menyelesaikan masalah yang ada pada LKS dan soal-soal mandiri yang diberikan.

Dari penjelasan di atas jelas terlihat bahwa prestasi belajar dalam penerapan model pembelajaran problem solving terhadap kemampauan menyelesaikan soal-soal yang berkaitan dengan pembelajaran fisika lebih antusias, aktif dan kreatif. Hal ini dapat terjadi karena dalam model pembelajaran problem solving diupayakan dengan pendekatan soal-soal dan masalah-masalah dengan situasi dunia nyata yang mereka alami dalam kehidupan sehari-hari.

\section{SIMPULAN DAN SARAN}

Berdasarkan sajian hasil yang diperoleh dari pelaksanaan tindakan awal, siklus I dan siklus II pembahasan seperti diuraikan pada bab IV, dapat ditarik kesimpulan : Prestasi belajar fisika siswa pada awalnya rata-rata klasikal ( $\overline{\mathrm{X}}$ )adalah 62,61 berada pada kategori urang, sedangkan pada siklus I rata-rata klasikal $(\overline{\mathrm{X}})$ adalah 81,56 , berada pada kategori baik dan pada siklus II rata-rata klasikal $(\overline{\mathrm{X}})$ adalah 83,65 , berada pada kategori baik setelah dikonfirmasikan dengan pedoman yang ditetapkan. Dengan demikian data awal apabila dibandingkan dengan siklus I meningkat $\bar{X}_{1}-X_{2}=81,56-62,61=$ 18,95 , sedangkan untuk siklus I ke siklus II meningkat $\bar{X}_{2}-\bar{X}_{3}=83,65-81,56=$ 2,09. Demikian juga daya serap pada awalnya sebesar $62,61 \%$, pada siklus I sebesar $81,56 \%$ dan pada siklus II meningkat menjadi $83,65 \%$.

a. Ketuntasan belajar (KB) pada awalnya adalah $23,26 \%$, pada siklus I sebesar $90,70 \%$ dan pada siklus II meningkat menjadi $100 \%$.

Peningkatan ini dinilai cukup signifikan mengingat siswa kelas XII IPA 6 yang menjadi subjek penelitian nilai rata-rata berkemampuan sedang dan kurang. Dengan demikian hipotesis yang berbunyi "penerapan model pembelajaran problem solving dapatmeningkatkan prestasi belajar fisika siswa kelas XII IPA 6semester I SMA Negeri 2 Denpasar tahun ajaran 2017/ 2018" ternyata terbukti.

\section{DAFTAR PUSTAKA}

Arikunto, Suharsimi. (1995). Dasar-Dasar Evaluasi Pendidikan. Jakarta: Bumi Aksara.

Arikunto, Suharsimi, Suhardjono, Supardi. (2006). Penelitian Tindakan Kelas. Jakarta: PT Bumi Aksara.

Badan Standar Nasional Pendidikan. (2007). Peraturan Menteri Pendidikan Nasional Republik Indonesia Nomor 41 Tahun 2007. Jakarta: BSNP.

Djamarah, Syaful Bahri. (2002). Prestasi Belajar dan Kompetensi Guru. Surabaya: Usaha Nasional.

Slameto. (2003). Belajar dan Faktor-faktor yang Mempengaruhinya. Jakarta: Rineka Cipta.

Slavin, Robert E. (1995). Cooperative Learning : Theory, Research, and Practice.Boston: Allyn and Bacon.

Wardani, I. G. A. K Siti Julaeha. Modul IDIK 4307. Pemantapan Kemampuan Mengajar. Jakarta: Universitas Terbuka.

Wina Sanjaya. (2006). Strategi Pembelajaran Berorientasi Standar Proses Pendidikan. Kencana Prenada Media: Jakarta. 